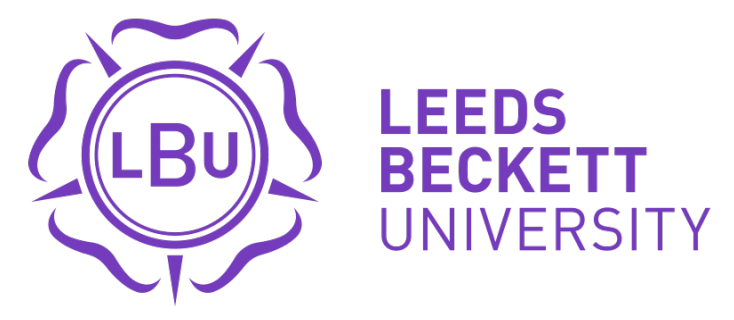

Citation:

Kostopoulos, I and Gounaris, S and Rizomyliotis, I (2014) How to reduce the negative impact of customer non-compliance: an empirical study. Journal of Strategic Marketing, 22 (6). 513 - 529. ISSN 0965-254X DOI: https://doi.org/10.1080/0965254X.2014.914056

Link to Leeds Beckett Repository record:

https://eprints.leedsbeckett.ac.uk/id/eprint/1575/

Document Version:

Article (Updated Version)

The aim of the Leeds Beckett Repository is to provide open access to our research, as required by funder policies and permitted by publishers and copyright law.

The Leeds Beckett repository holds a wide range of publications, each of which has been checked for copyright and the relevant embargo period has been applied by the Research Services team.

We operate on a standard take-down policy. If you are the author or publisher of an output and you would like it removed from the repository, please contact us and we will investigate on a case-by-case basis.

Each thesis in the repository has been cleared where necessary by the author for third party copyright. If you would like a thesis to be removed from the repository or believe there is an issue with copyright, please contact us on openaccess@leedsbeckett.ac.uk and we will investigate on a case-by-case basis. 


\title{
How to Reduce the Negative Impact of Customer Non-Compliance: An empirical study
}

\begin{abstract}
This article focuses on the notion of customer non-compliance with front line employees' instructions and company's policies during the service encounter. The aim of the study is to offer an alternative solution to the issue of customer non- compliance, exploring the factors that reduce its negative impact on service quality. For that reason, we developed a conceptual framework integrating the negative influence of customer non-compliance on perceived service quality with three moderating effects. To test the validity of the framework, a hierarchical approach was followed and data were collected from 120 managers and 585 customers of 120 hotels. The results confirm the negative influence of customer non-compliance on perceived service quality and indicate three organizational factors as reducing moderators of this influence: customer orientation, service blueprinting effectiveness and employee empowerment. Based on these conclusions, important implications for academics and practitioners are drawn.
\end{abstract}

Keywords: Customer non-compliance, service quality, service blueprinting, Customer orientation 


\section{Introduction}

In the past few decades marketing scholars argue that service organizations should not only encourage customer participation but also consider customers as "partial employees" (e.g. Mills \& Morris, 1986; Kelley, Skinner, \& Donnelly, 1992; Hsieh, Yen, \& Chin, 2004). According to this approach, customers can enact employees' role in many steps of the service delivery and companies should invest in their adequate education as well as in specific "participation" initiatives in order to improve their performance (Kelley, Skinner, \& Donnelly, 1992; Grönroos \& Ojasalo, 2004)

However, in practice the integration of customers as "partial employees" in the value cocreation process is not an easy task (Dong, Evans, \& Zou, 2008). When customers are involved in the service provision, an additional parameter is incorporated in the service system, which cannot be absolutely predicted and controlled by the company. Therefore, customer participation can be a significant source of service heterogeneity which makes the company's effort to standardise the service offering and maintain an efficient service delivery process very difficult (Lovelock, 1983; Grönroos \& Ojasalo, 2004). In such cases, service providers depend on customer' performance as "partial employees" to achieve high levels of service quality and customer satisfaction.

Since customers are an inseparable part of the service process, it becomes clear that whether their participation has an enabling or a coercive impact on the service delivery depends on their behaviour during the encounter and the company's actions to align this behaviour to the predefined service procedures. To this end a very important concept is customer compliance, which is defined as the extent to which customers follow front line employees' instructions and the service provider's policies and procedures (Hausman, 2004, Dellande, Gilly, \& Graham, 2004; Kasabov \& Warlow, 2010). In the present study we focus on this important 
concept, aiming to understand its implications on the service outcome, as well as the organizational practices that reduce the negative impact of low customer compliance.

In the following paragraphs we present the underlying theory regarding the notion of customer compliance. Next, we develop the research hypotheses of the study's conceptual framework. Then, we discuss the methodology as well as the results of our empirical investigation. In conclusion, we address the implications of our findings along with the limitations of the present study while also offering directions for future research.

\section{Literature Review and Research Hypotheses}

\subsection{The Issue of Customer Non-Compliance and Alternative Ways to Deal with It}

As explained in the introductory part of this paper, the co-creation of service value is not an easy task, as customers' presence during the service encounter can be both a hazard and an opportunity for service providers (Dong, Evans, \& Zou, 2008). On one side, customer participation in the service delivery can potentially restrict the company's ability to provide the service promised to the customer and hence reduce the reliability of the service system. This is because although customers co-create the service, they are not professional providers and do not necessarily have the ability and/or the willingness to effectively participate in the service delivery process (Prahaland \& Ramaswamy, 2004). However, service organisations still need to incorporate them as co-responsible in the development of the company's endservice, as they are inseparable part of the value co-creation (Vargo, Maglio, \& Akaka, 2008).

On the other hand, the intensive participation of customers in the service delivery has been proved to improve significantly their perception of service quality as well as their overall satisfaction with the service encounter (Kelley, Skinner \& Donnelly, 1992; Bagozzi \& Dholakia, 1999; Bendapudi \& Leone, 2003). This is because their active participation reinforces their sense of customised experience, as not only they can provide the employees 
with information regarding their needs and preferences, but also they can execute some of the tasks themselves (Bettencourt, 1997). Also, by allocating a proportion of the service delivery to customers, service providers save costs, decrease delivery time and hence increase productivity and efficiency (Claycomb, Lengnick-Hall, \& Inks, 2001).

Due to customers' critical but ambiguous role as part of the service process, service organizations can be either benefited or harmed from customers' willingness and ability to comply with specific instructions and procedures. Hence, customer compliance is a very important concept which has received increased attention in the marketing literature. Customer compliance has been theoretically and empirically examined by many scholars in various contexts such as health care services (Hausman, 2004; Dellande, Gilly, \& Graham, 2004), b2b sales and supporting services (Joshi \& Arnold, 1997; 1998) and other high contact services (Lin \& Hsieh, 2011). Much of this research has been focused on the organizational factors that ensure customers' complying behaviour during the service encounter. Among others, the factors include the standardization of the service procedures, the trust between the company and the customer, the company's customer orientation and the employees' friendliness (Dellande, Gilly, \& Graham, 2004; Kasabov \& Warlow, 2010; Lin \& Hsieh, 2011).

A service provider seeking to increase the efficiency of the service delivery process achieving leverage from customers' participation should embrace the aforementioned practices. However, although the effort to improve customer participation through minimizing customers' non compliance is necessary, it is subject to certain limitations. Specifically, according to the Social Cognitive Theory, the level of customers' compliance is determined by a) factors controlled by the company such as the front line employees' behaviour, clarity of instructions to customers e.t.c. and b) factors that cannot be controlled by the company, such 
as customers' personality, individual characteristics, mood e.t.c.(Bandura, 1977; Yim, Chan \& Lam, 2012).

Service providers invest in managing the first category of factors in order to minimise the part of non-compliance that is due to those factors. However, since the second category of factors is uncontrollable by the service provider, there will always be cases where customers won't comply with the instructions due to those factors (Dellande, Gilly, \& Graham, 2004). This means that the part of non-compliance that derives from customers' personalality, indicidual characteristics e.t.c can not be eliminated and therefore service providers must find alternative means to deal with it. Surprisingly, the pertinent literature has focused only in finding ways to reduce non-compliance and very few arguments have been expressed on how companies should handle such behaviour, when they occur.

The present study offers solution to this issue and contributes to the pertinent theory, by suggesting an alternative approach for dealing with customers' non compliance. Specifically, we propose that, apart from trying to reduce non-compliance, service providers should also invest in organizational practices that reduce its negative impact when this impact occurs both due to ineffective control of the first category of factors (front line employees' behaviour, clarity of instructions e.t.c.) or due to the second category of factors (customers' personality, $\operatorname{mood}$ e.t.c.).

Our approach is based on a large steam of research findings which suggest that during the service encounter customers can be considered as "partial employees", particularly due to their individual knowledge, ability and personal needs' awareness (Bitner, Faranda, Hubbert, \& Zeithaml, 1997; Bowen, 2006). On this basis, we argue that customers' divergent behaviour has not necessarily a negative impact on the service outcome. The negative influence of customers' coercive participation exists only if the service provider is not adequately prepared for this kind of behaviour (Cermak, File \& Prince, 2011). If the company 
and especially the front line employees have the necessary capabilities and resources to integrate divergent customer behaviour in the pre-defined service delivery plan, the efficiency of the service procedures won't be significantly influenced. Effective service procedures allow such divergences, without increasing the time or the cost of tasks' execution (Zeithaml \& Bitner, 2000).

In fact, in many cases customers' divergent behaviour improves their perception on service quality and increases their satisfaction during the service encounter, both if this behaviour is due to the company's inability to convince the customers to cooperate and due to customers' personality. For instance, in the case of a service failure customers' initiative, even if not required from the personnel, can restore the quality of the service outcome and hence lead to “Co-created Service Recovery” (Dong, Evans, \& Zou, 2008). Also, especially in high-contact services, allowing customers to take some initiatives and act outside employees' directions makes them understand that the service provider evaluates their role as more important (Yi, Nataraajan \& Gong, 2011). In all these cases, customers will perceive the service offering as more customised, which in turn will improve the overall evaluation of the provided service (Johnston, 1995; Gwinner, Bitner, Brown, \& Kumar, 2005).

Based on the above reasoning, in the present study we focus on the organizational practices that make customers' coercive participation in the service delivery process less influential and we investigate the factors that reduce the negative impact of customer non-compliance on the quality of the service outcome. In the following paragraphs we present a detailed literature review that led as to formulate this study's conceptual framework (Figure 1) which consists of the relationship between customer non-compliance and perceived service quality, as well as the factors that negatively moderate this relationship.

\section{Insert here Figure 1}




\subsection{The Negative Impact of Customer Non-Compliance on Perceived Service Quality}

In the previous paragraph we presented the review of the literature regarding customer compliance with a company's instructions during the service encounter. From all the theoretical arguments presented above it becomes clear that service providers pursue customers' compliance in order to avoid problems in the service delivery (e.g. Bitner, Faranda, Hubbert, \& Zeithaml, 1997; Lin \& Hsieh, 2011). In this section, we deliberate the negative influence of customer non-compliance by exploring its direct influence on customers' perceptions over the quality of the service they receive.

During the service encounter, customers who follow front line employees' instructions can better enact their role in the service delivery process (Dong, Evans, \& Zou, 2008). This helps the company to effectively implement the service plan and meet the predefined quality standards (Kasabov \& Warlow, 2010). Also, it helps the company standardise the service process and offer a more reliable service to customers. Increased service reliability improves customers' evaluation on the overall service quality for two reasons. From the company's perspective, delivering a reliable service means that the company has reduced the heterogeneity of the service outcome both at the front-desk and the back-office levels. As a result, service failures become less frequent and the cost resulting from service recovery efforts decreases (Edvardsson, Gustafsson, \& Roos, 2005). It is equally important that the company delivers the level of service originally promised to customers, while achieving high levels of quality, especially if the customers have been offered the service again in the past (Lemke, Clark \& Wilson, 2011)

Apart from the improvement of service quality due to the enhancement of the service delivery process, customers' compliance with the company's instructions has also a positive psychological effect on them. During the service provision, customers often have no clear 
understanding on the way the service is delivered due to the "mental intangibility" of the service (Laroche et al, 2001). Hence, they are ambiguous about their role and do not enjoy the overall "service experience" (Meuter, Bitner, Ostrom, \& Brown, 2005). In cases when customers don't follow employees' instructions, their role ambiguity increases and their experience is downgraded. Hence, their perceptions on the quality of the service offered to them become worse (Dabholkar, 1996; Walsh, \& Mitchell, 2010).

Based on the above discussion we state that, unless service providers take the necessary actions, customers' compliance has a negative impact on the outcome of the service delivery process. Hence our first research hypothesis is:

H1: Increased customers' non-compliance influences negatively their perception on the quality of the provided service.

\subsection{Organizational Factors that Reduce the Impact of Customer non-Compliance}

\subsubsection{Customer Orientation}

In order to minimise the negative impact of customers' non compliance with the predesigned service procedures, service providers must at first be able to predict it. To do so, they must generate and disseminate customer intelligence and hence embrace a customer oriented philosophy (Narver \& Slater, 1990; Kohli \& Jaworski, 1993). A service organization that knows its customers will find it easier to predict divergent behaviours, their impact on the service delivery process and the reasons why the customer chose not to follow the employees' instructions or the company's overall plan (Wang, Beatty, \& Liu, 2012). Developing such knowledge will allow the management team to evaluate the possible divergences that can cause a significant problem to the service delivery process and pre-define specific procedures to deal with them. 
Moreover, a customer oriented philosophy not only reduces the negative impact of customers' non compliance, but also improves the levels of service quality when the customer actually follows the pre-defined service scripts. This is because if customers align with the companies' procedures, they will expect that these procedures have been developed in such way that customers' needs and preferences are incorporated (Yim, Chan, \& Lam, 2012). If not they will feel that they receive no customised experience and evaluate the service poorly (Zeithaml, Berry \& Parasuraman, 1996). Customer driven companies develop service procedures that fit adequately to customers' individual needs (Chang \& Chen, 1998) and hence customers will feel that their choice to comply with the instructions was worthwhile. In such cases, customers have an additional reason to evaluate the service positively.

All the above discussion proves that customer orientation is a significant factor for overcoming non-compliance's coercive influence and hence leads us to formulate the following research hypothesis:

H2: Customer orientation reduces the negative impact of customer non-compliance on perceived service quality.

\subsubsection{Service Blueprinting}

After generating and disseminating the necessary customer knowledge, service providers should ensure that this knowledge will be always available to the first line employees who are responsible for instructing the customer during the service provision and handling all non compliance cases. A very effective and efficient way to do so is through the use of Service Blueprints (Bitner, Ostrom, \& Morgan, 2008).

The Service Blueprinting (SB) method was firstly introduced by Shostack (1982; 1984; 1987) in the early eighties and since then it has been often used by service providers as a tool for designing and managing service processes. In a blueprint all sequences and steps of the service delivery process are graphically presented in a two-dimensional flowchart (Shostack, 
1982). Additionally, all steps and processes are structured and assorted by four lines which are also included in the blueprint (Kingman-Brundage, 1989; Fliess \& Kleinaltenkamp, 2004). Although the way this process is carried out varies from company to company, in general, the SB design process includes four steps: the identification of all necessary processes, the isolation of fail points, the establishment of time frames, and a cost - profit analysis (Shostack, 1984).

Through the past three decades, many scholars have demonstrated different applications of SB in new service development (Fache, 2000), internal marketing practices (Lings \& Brooks, 1998), the management and control of existing service processes (Shostack, 1984; 1987, Fließ \& Kleinaltenkamp, 2004) and customer preferences' monitoring (Randall, 1993). Also, SB has been proven to have a beneficial influence on the customers' end experience both in terms of service quality and customer satisfaction (Polonsky \& Garma, 2006; Lusch, Vargo, \& O'Brien 2007) mainly due to the incorporation of the customer's view in the service design process (Randall, 1993; Bitner, Ostrom, \& Morgan, 2008).

One of the main reasons why the use of blueprints can improve the quality of customers' experience is that the integration of customers' view into a service blueprint can help front line employees to cope with customer non-compliance. An effective SB includes multiple employees' responses to customers' requests. Hence, during the service encounter if a customer doesn't follow the employees' instructions, the front line personnel can easily deliver the predefined plan following the blueprint, which allows for such divergences (Shostack, 1984). If this is not possible because the customer's behaviour is too divergent from the original script, front line employees could use the blueprints to offer an alternative service scenario to the customer. In both cases, the negative influence of non-compliance on service quality will be reduced.

On the other hand, if the customer enacts correctly the role the company allocated to him, the service delivery process gains more efficiency and reliability as long as the company has previously designed effectively a service blueprint. In these cases, since customers are 
handled as "partial employees" (Mills \& Morris, 1986; Bitner, Faranda, Hubbert, \& Zeithaml, 1997), with the use of blueprints, service providers can better fit their behaviour to the rest of the activities involved in the service delivery process and avoid inefficiencies, such as double efforts, bottlenecks e.t.c. (Ling \& Brooks, 1998; Fliess \& Kleinaltenkamp, 2004). Therefore, the quality of the service outcome will be improved. Based on the above reasoning we post that:

H3: The effectiveness of the Service Blueprinting process reduces the negative impact of customer non-compliance on perceived service quality.

\subsubsection{Employee Empowerment}

Employee empowerment is a situation in which, "employees have the freedom to take initiatives and make day to day decisions regarding their job tasks” (Bowen \& Lawler, 1992). For service providers, empowering front line employees is crucial in order to achieve high levels of service quality and customer satisfaction (Hartline \& Ferrel, 1996; Chebat \& Kollias, 2000).

Employee empowerment improves customers' experience, mainly because empowered front line employees can better adjust their behaviour to individual customer preferences (Ahearne, Mathieu, \& Rapp, 2005). Having the discretion to take initiatives and change their role during the service encounter, employees are able to go beyond the pre-defined script and handle unexpected customers' behaviour or unpredicted requests (Scott \& Bruce, 1994; Combs, Liu, Hall, \& Ketchen, 2006). Hence, even if the customer doesn't comply with the instructions, the front line personnel will be able to alter the service provision and handle this non-compliance effectively. In that way, the negative impact of non-compliance is reduced and the levels of the outcome quality are retained. 
Moreover, in such cases the initiatives taken from empowered front line employees are perceived from customers as an attempt to customise the service (O'Cass \& Ngo, 2011). This perception combined with customers', divergent from the instructions, behaviour leaves the impression of individual attention and empathy, which in turn improve the perceptions on the quality of the service offering (Parasuraman, Zeithaml, \& Berry, 1985), again reducing the negative impact of their low or no compliance. Based on the above discussion we formulate the following research hypothesis:

H4: Front line employees' empowerment reduces the negative impact of customer noncompliance on perceived service quality.

\section{Methodology}

\subsection{Sample and Data Collection}

In order to empirical test our research hypotheses we collected data from the hotel service sector. Since the conceptual framework includes both customer and organizational variables, we collected data from both managers and customers. For that reason, two different questionnaires were designed, one for hotel managers and one for customers. Data collection was carried out through a two-stage cluster sampling method. First, 389 hotels were randomly selected from the total population of hotels in large cities in Greece. In defining the population we excluded relatively smaller hotels (with capacity equal or less of 100 beds), since such hotels employ a significant lower number of employees (Table 1 presents the profile of the hotels included in our sample). From the 389 hotels we contacted, 120 agreed to participate in our study, resulting in a response rate of $31 \%$.

\section{Insert Table 1 around here}

Then, to collect the necessary organizational data we followed the "key informant" method (Kumar, Stern, \& Anderson, 1993). Hence, in each hotel a structured questionnaire was 
completed by a manager who had a good knowledge of the hotel's service design procedures, general philosophy and employee management, such as operations director, marketing director or general manager (for the complete list of the key informants see Table 2).

\section{Insert Table 2 around here}

To collect the data regarding the customer variables, we asked each hotel's management to provide us with a list of their guests aiming to select five customers from each hotel. Then, we randomly selected five customers from each hotel contacting every nth customer from each list where $\mathrm{n}=$ the absolute value of the quotient of the number of customers included in each list divided by four. Customers who refused to participate were replaced with the next available customer from each hotel's unique sample frame, without destructing the overall selection rule for each hotel. With the hotels' management approval, customers who agreed to participate in the study were personally interviewed on the premises (Table 3 presents the demographic profile of the participants, as well as the purpose of their visit). After discarding 15 unusable customer questionnaires, the total sample consisted of 120 questionnaires from managers and 585 questionnaires from customers.

The number of the customer responses collected in each hotel is relatively small. However, from an HLM perspective, a group of 5 observations in macro-level (level 1) is adequate since it allows a certain degree of variability among micro-level (level 2) members (hotels) and therefore the regression coefficients and the variance components are all estimated without significant bias (Maas \& Hox, 2005). Also, a number of 5 observations in Level 1 is widely accepted from social scientists and used many time in previous pertinent studies (e.g. Homburg \& Fürst, 2005; Molina-Azorin, Pereira-Moliner \& Claver-Cortés, 2010).

\section{Insert Table 3 around here}




\subsection{Operationalization of Variables}

For most of the study's constructs we employed existing scales which have been formerly developed and tested by previous researchers. Specifically, to measure customer noncompliance we used a scale of 7 reversed items adopted from the scales initially developed from Bettencourt (1997) and Dellande, Gilly and Graham (2004). The assessment of customer's perceptions of service quality relies on the 22 items of the SERVPERF model proposed by Cronin and Taylor (1992), whereas customer orientation was measured with the scale proposed by Narver and Slater (1990) and employee empowerment with the scale of Hartline and Ferrell (1996). Finally, SB effectiveness was measured by a scale developed by Kostopoulos, Gounaris anf Boukis (2012). The items we included in all scales, presented in detail in Table 4, were 7point Likert-type, with anchors ranging from strongly disagree (1) to strongly agree (7).

\section{Insert Table 4 around here}

Confirmatory factor analysis (CFA) was employed (Table 5) in order to examine all scales' unidimensionality and discriminant as well as convergent validity. To do so we used the EQS 6.2 software. As can be seen from Table 5, the measures were indeed proven to be unidimensional and valid in terms of discriminant and convergent validity. All measures were also found internally consistent as reflected by construct reliability, which was assessed through Cronbach a and Composite Reliability.

\section{Insert Table 5 around here}

Finally, as described in Table 6 the values of the Kurtosis and Asymmetry coefficients for all variables are between -1 and 1 . Also, the p-value of the Kolmogorov-Smirnov normality test for all variables is above 0.01 and for most of them above 0.05 . This indicates that the summative variables used can be considered continuous and that they in approximation follow 
a normal distribution (Table 6 also presents all variables' most important descriptive statistics).

\section{Insert Table 6 around here}

\section{Data Analysis}

In order to test the validity of our conceptual framework, we combined data collected from both managers and customers of the hotels. For that reason, we employed Hierarchical Linear Modelling (Raudenbush \& Bryk, 2001) using service quality and customer noncompliance as level-1 variables and customer orientation, SB effectiveness and employee empowerment as level-2 variables. Thus, our hierarchical model consists of two levels, the customer level (level 1) and the hotel level (level 2). All level 1 variables were grand-mean centred, as recommended by Hofmann and Gavin (1998). The software we used for this analysis was HLM 7.

Since our customer data are nested within each hotel (Byrne, 2006), we first run the analysis for the null model, having service quality as a predicted variable and no predictors at either level 1 or level 2 . As indicated from the results of the analysis of level $1\left(x^{2}=320,62 /\right.$ $\mathrm{p}<0,01)$ the intercept term varies across groups, which means that customer data are indeed nested within each hotel and hence a hierarchical approach is appropriate. This conclusion is also confirmed from the intraclass correlation coefficient (ICC) of the predicted variable which shows that $39 \%$ of this variable's variance could potentially be explained by the level-2 predictor (Bryk \& Raudenbush 1992).

After the confirmation of the suitability of the hierarchical approach, we tested the validity of a Hierarchical Linear Model with service quality as a dependent variable and customer non-compliance as well as its interaction with the three organizational variables as predictors. 
The interaction terms were computed by multiplying the corresponding variables. On this basis, he overall linear model is the following:

$\mathrm{SQij}=\gamma 00+\gamma 10 * \mathrm{NCij}+\gamma 11 * \mathrm{COj} * \mathrm{NCij}+\gamma 12 * \mathrm{SBj}^{*} \mathrm{NCij}+\gamma 13 * \mathrm{EMPj}^{*} \mathrm{NCij}+\mathrm{u} 0 \mathrm{j}+\mathrm{rij}$

\section{Where,}

SQ: Service Quality, NC: Customer Non-Compliance, CO: Customer Orientation, $\mathbf{S B}$ : Service Blueprinting Effectiveness, EMP: Employee Empowerment

\section{Insert Table 7 around here}

As shown from the results of the analysis (Table 7), service quality is significantly and negatively influenced by customer non-compliance $(\gamma=-0,18 / \mathrm{SE}=0,04 / \mathrm{p}<0,001)$, whereas significantly and positively influenced by the three interaction terms of customer compliance with customer orientation $(\gamma=0,13 / \mathrm{SE}=0,03 / \mathrm{p}<0,001), \mathrm{SB}$ effectiveness $(\gamma=0,15 / \mathrm{SE}=0,06 /$ $\mathrm{p}<0,001)$ and empowerment $(\gamma=0,14 / \mathrm{SE}=0,04 / \mathrm{p}<0,001)$. These results confirm all four research hypotheses and therefore indicate that there is a negative relationship between customer non-compliance and service quality, which is negatively moderated (reduced) by the three aforementioned organizational variables.5. Conclusions - Discussion

The main objective of the present study is to investigate the organizational practices that reduce the negative impact of customer non-compliance on the outcome of the service delivery process. As we previously explained, part of consumers' refusal to comply with the given instructions derives from factors uncontrollable from the service provider (e.g. customers' personality, character, habits etc). For that reason, apart from trying to prevent customers' non compliance from happening, service providers must find ways to deal with it when it happens. To this end the results of our study identify several organisational practices reduce the influence of customer non-compliance on service quality, which in this research 
was found negative in agreement with previous studies (e.g. Kasabov \& Warlow, 2010; Lin \& Hsieh, 2011). Specifically, the results of the analysis indicate that three organizational variables have a negative moderating effect on the aforementioned relationship: customer orientation, SB effectiveness and employee empowerment.

Previous research has shown that a good knowledge of customer preferences and potential behaviour is essential in order to deal with customers' non compliance (Wang, Beatty, \& Liu, 2012). This study expands this conclusion by proving that a customer oriented service provider will find it easier to generate customer knowledge (Kohli \& Jaworski, 1993), to predict when divergent customer behaviours will occur and to find solutions to cope with it (Deshpandé, Farley \& Webster, 1993). This alternative approach indicates that a customer oriented philosophy minimise the negative impact of the remaining divergent customer behaviour, which cannot be controlled and eliminated by the company.

The next important conclusion of the present study is that the use of effective blueprints enables the detailed and accurate description of possible solutions to customer noncompliance and therefore provides the front line employees with the necessary tools to deal with it. Since Service Blueprinting was firstly introduced to the literature (Shostack, 1982; 1984), there are very few empirical evidences on the exact benefits from the effective use of this technique and in particular on how the use of such techniques can help service providers deal with customers' low or non compliance. The present research contributes to the pertinent theory, by explaining how blueprinting procedures are used by service providers to predict situations where might show low compliance with the given instructions and help them predefine scenarios to overcome possible negative implications of such undesired customer behaviours. In that way, front line employees have an additional tool to cope with customers' reduced compliance with the pre-defined plan. This conclusion encourages service providers, not only to use service blueprints in the design of the service delivery process, but also to 
incorporate in these blueprints as many as possible alternative scenarios to deal with unexpected or divergent customer behaviours.

Finally, this study's results prove that empowered employees can more effectively go beyond the pre-defined script and handle unexpected customers' behaviour or unpredicted requests (Hartline \& Ferrell, 1996) and hence they can more effectively deal with customer non-compliance. For that reason, service providers should invest in enabling front line employees' ability to take initiatives and try to decentralise decision making, especially for service encounter related decisions. In that way, employees who interact with customers that don't follow the instructions will find it easier to deal with such non-compliance situations reducing their negative impact on the service outcome, since they will have more latitude to adjust the service provision to the divergent behaviour and will be able to deliver high levels of service quality.

From all this his discussion it becomes apparent that service providers should invest in developing the necessary customer orientation as well as the appropriate organizational practices (service blueprinting, empowerment) to reduce the negative impact of customer noncompliance. In that way the quality of the service outcome will be less influenced by customers' divergent behaviour and the company will execute the service plan more effectively, ensuring the desired levels of customer satisfaction. This alternative solution for dealing with non-compliance is very important because, as previously explained the part of non-compliance that is due to customers' individual characteristics cannot be prevented, will occur nevertheless and the only thing a service provider can do is to minimise its negative influence on the service outcome. 


\section{Limitations and Suggestions for Further Research}

Certain limitations of the present study should be considered. The first limitation has to do with the conceptual framework of this investigation and particularly with the relatively limited breadth of the conceptualization. Future research should examine additional organizational practices that may reduce the negative impact of customer non-compliance as well as other service outcomes apart from perceived service quality. Another limitation is that the present study does not distinguish between high-contact and low contact services. The level of contact between the customers and the company has been proven to be an important factor in customer participation and value co-creation and therefore should be integrated in any future research on this subject. On this basis, the results of this study could be tested in both low contact services (self-service, internet services) and high contact ones (health care, entertainment) to enhance the generalisability of the conclusions. Also, future research could examine the differences between first time and repeated customers, since different conclusions may be dran for customers that have previously experienced the service in the past.

Another limitation of the study has to do with the measurement of the organizational variables only in a managerial level. In future research, employee related measures could also be incorporated, adding another level to the hierarchical approach used to test the study's conceptual framework. Finally, another limitation pertains in the relatively small size of the observations collected from each hotel. Although, the size of the samples collected in this study are acceptable, future studies should consider collecting larger samples to enhance the reliability of the study's results. 


\section{References}

Ahearne, M., Mathieu, J., \& Rapp, A. (2005). To empower or not to empower your sales force? An empirical examination of the influence of leadership empowerment behaviour on customer satisfaction and performance. Journal of Applied Psychology, 90(5), 945-955. doi: 10.1037/0021-9010.90.5.945

Bagozzi, R. P., \& Dholakia, U. (1999). Goal setting and goal striving in consumer behaviour. Journal of Marketing, 63, 19-32. doi: 10.2307/1252098

Bandura, A. (1977). Social learning theory. Englewood Cliffs, NJ: Prentice-Hall.

Bendapudi, N., \& Leone, R. P. (2003). Psychological implications of customer participation in coproduction. Journal of Marketing, 67 (1), 14-28. http://dx.doi.org/10.1509/jmkg.67.1.14.18592 Bettencourt, L. A. (1997). Customer voluntary performance: customers as partners in service delivery. Journal of Retailing, 73(3), 383-406. doi: 10.1016/S0022-4359(97)90024-5

Bitner, M. J., Faranda, W. T., Hubbert, A. R., \& Zeithaml, V. A. (1997). Customer contributions and roles in service delivery. International Journal of Service Industry Management, 8(3), 193-205. doi: $10.1108 / 09564239710185398$

Bitner, M., Ostrom, A., \& Morgan, F. (2008). Service blueprinting: A practical technique for service innovation. California Management Review, 50(3), 66 - 94. doi: 10.1225/CMR397

Bowen, D. E. (2006). Managing customers as human resources in service organizations. Human Resource Management, 25(3), 371-383. doi: 10.1002/3930250304

Bowen, D. E., \& Lawler, E. E. (1992). Total quality-oriented human resources management. Organizational Dynamics, 20(4), 29-41. doi: 10.1002/hrm.3930250304

Bryk, A. S., \& Raudenbush, S. W. (1992). Hierarchical linear model: Applications and data analysis methods. Newbury Park, CA: Sage. 
Byrne, B. M. (2006). Structural Equation Modeling with EQS, 2nd Edition, Multivariate Applications Series.

Cermak, D. S., File, K. M., \& Prince, R. A. (2011). Customer participation in service specification and delivery. Journal of Applied Business Research, 10(2), 90-97. doi: $10.1177 / 0149206304271375$

Chang, T. Z., \& Chen, S. J. (1998). Market orientation, service quality and business profitability: a conceptual model and empirical evidence. Journal of Services Marketing, 12(4), 246-264. doi: $10.1108 / 08876049810226937$

Chebat, J. C., \& Kollias, P. (2000). The impact of empowerment on customer contact employees' roles in service organizations. Journal of Service Research, 3(1), 66-81. doi: $10.1177 / 109467050031005$

Claycomb, C., Lengnick-Hall, C. A., \& Inks, L. W. (2001). The customer as a productive resource: A pilot study and strategic implications. Journal of Business Strategies, 18(1), 47-69.

Combs, J., Liu, Y., Hall, A., \& Ketchen, D. (2006). How much do high-performance work practices matter? A meta-analysis of their effects on organizational performance. Personnel Psychology, 59(3), 501-528. doi: 10.1111/j.1744-6570.2006.00045.x

Cronin, J. J., \& Taylor, S. A. (1992). Measuring service quality: a reexamination and extension. Journal of Marketing, 56 (3), 55-68. 1252296

Dabholkar, P. A. (1996). Consumer evaluations of new technology-based self-service options: An investigation of alternative models of service quality. International Journal of Research in Marketing, 13(1), 29-51. doi: 10.1016/0167-8116(95)00027-5

Dellande, S., Gilly, M.C., \& Graham, J.L. (2004). Gaining compliance and losing weight: The Role of the service provider in health care services. Journal of Marketing, 68(2), 78-91. doi: 10.1509/jmkg.68.3.78.34764 
Deshpande, R., Farley, J.U. \& Webster, F.E. (1993). Corporate culture customer orientation, and innovativeness in Japanese Firms: A quadrad analysis. Journal of Marketing, 57(1), 23-37. 1252055

Dong, B., Evans, K. R. \& Zou, S. (2008). The effects of customer participation in co-created service recovery. Journal of the Academy of Marketing Science, 36(1), 123-137. 10.1007/s11747-0070059-8

Edvardsson, B., Gustafsson, A., \& Roos, I. (2005). Service portraits in service research: a critical review. International Journal of Service Industry Management, 16(1), 107-121. doi: $10.1108 / 09564230510587177$

Faché, W. (2000). Methodologies for innovation and improvement of services in tourism. Managing Service Quality, 10(6), 356-366. doi: 10.1108/09604520010351185

Fließ, S., \& Kleinaltenkamp, M. (2004). Blueprinting the service company: Managing service processes efficiently. Journal of Business Research, 57(4), 392-404. doi: 10.1016/S01482963(02)00273-4

Grönroos, C., \& Ojasalo, K. (2004). Service productivity: Towards a conceptualization of the transformation of inputs into economic results in services. Journal of Business Research, 57(4), 414-423. doi: 10.1016/S0148-2963(02)00275-8

Gwinner, K. P., Bitner, M. J., Brown, S. W., \& Kumar, A. (2005). Service customization through employee adaptiveness. Journal of Service Research, 8(2), 131-148. doi: $10.1177 / 1094670505279699$

Hartline, M. D., \& Ferrell O. C. (1996). The management of customer-contact service employees: An empirical investigation. Journal of Marketing, 60(4), 52-70. doi: 10.2307/1251901 
Hausman, A. (2004). Modelling the patient-physician service encounter: improving patient outcomes. Journal of the Academy of Marketing Science, 32(4), 403-417. doi: $10.1177 / 0092070304265627$

Hofmann, D. A., \& Gavin, M. B. (1998). Centering decisions in hierarchical linear models: Implications for research in organizations. Journal of Management, 24(5), 623-641. doi: $10.1016 / \mathrm{S} 0149-2063(99) 80077-4$

Homburg, C., \& Fürst, A. (2005). How organizational complaint handling drives customer loyalty: an analysis of the mechanistic and the organic approach. Journal of Marketing, 95-114. doi:10.1509/jmkg.69.3.95.66367

Hsieh, A. T., Yen, C. H., \& Chin, K. C. (2004). Participative customers as partial employees and service provider workload. International Journal of Service Industry Management, 15(2), 187199. doi: $10.1108 / 09564230410532501$

Jaworski, B. J., \& Kohli, A. K. (1993). Market orientation: antecedents and consequences. Journal of Marketing, 57 (3), 53-70. 1251854

Johnston, R. (2001). Linking complaint management to profit. International Journal of Service Industry Management, 12(1), 60-69. doi: 10.1108/09564230110382772

Joshi, A. W., \& Arnold, S. J. (1997). The impact of buyer dependence on buyer opportunism in buyer-supplier relationships: The moderating role of relational norms. Psychology and Marketing, 14(8), 823-845. doi: 10.1002/(SICI)1520-6793(199712)

Joshi, A.W. \& Arnold S.J. (1998). How relational norms affect compliance in industrial buying. Journal of Business Research, 41(2), 105-114. doi: 10.1016/S0148-2963(97)00017-9

Kasabov, E. and Warlow, A.J. (2010). Towards a new model of 'customer compliance' service provision. European Journal of Marketing, 44(6), 700-729. doi: 10.1108/03090561011032685 
Kelley, S. W., Longfellow, T., \& Malehorn, J. (1996). Organizational determinants of service employees' exercise of routine, creative, and deviant discretion. Journal of Retailing, 72(2), 135157. doi: 10.1016/S0022-4359(96)90011-1

Kelley, S. W., Skinner, S. J., \& Donnelly, J. H. Jr (1992). Organizational socialization of service customers. Journal of Business Research, 25(3), 197-214. doi: 10.1016/0148-2963(92)90029-B

Kingman-Brundage, J. (1989). The ABCs of service system blueprinting. Designing a winning service strategy, 30-33.

Kostopoulos, G., Gounaris, S. \& Boukis, A. (2012). Service blueprinting effectiveness: drivers of success. Managing Service Quality, 22 (6), 580 - 591. doi:10.1108/09604521211287552

Kumar, N., Stern, L. W., \& Anderson, J. C. (1993). Conducting interorganizational research using key informants. Academy of Management Journal, 36(6), 1633-1651. doi: 10.2307/256824

Lemke, F., Clark, M., \& Wilson, H. (2011). Customer experience quality: an exploration in business and consumer contexts using repertory grid technique. Journal of the Academy of Marketing Science, 39(6), 846-869. DOI: 10.1007/s11747-010-0219-0

Lin, J.C. \& Hsieh, C.C. (2011). Modelling service friendship and customer compliance in highcontact service relationships. Journal of Service Management, 22 (5), 607-631. doi: $10.1108 / 09564231111174979$

Lings, I. N., \& Brooks, R. F. (1998). Implementing and Measuring the Effectiveness of Internal Marketing. Journal of Marketing Management, 14(4), 325-351. doi: $10.1362 / 026725798784959426$

Lovelock, C. H. (1983). Classifying services to gain strategic marketing insights. Journal of Marketing, 47 (3), 9-20. 1251193 
Lusch, R. F., Vargo, S. L., \& O’Brien, M. (2007). Competing through service: Insights from servicedominant logic. Journal of Retailing, 83(1), 5-18. doi: 10.1016/j.jretai.2006.10.002

Maas, C. J., \& Hox, J. J. (2005). Sufficient sample sizes for multilevel modeling.Methodology: European Journal of Research Methods for the Behavioural and Social Sciences, 1(3), 86-92.

Meuter, M. L., Bitner, M.J., Ostrom, A. L. \& Brown, S.W., (2005). Choosing among alternative service delivery modes: An investigation of customer trial of self-service technologies. Journal of Marketing, 69 (2), 61-83. doi: 10.1509/jmkg.69.2.61.60759

Mills, P. K., \& Morris, J. H. (1986). Clients as 'partial' employees of service organizations: Role development in client participation. Academy of Management Review, 11(4), 726-735. 258392

Molina-Azorin, J. F., Pereira-Moliner, J., \& Claver-Cortés, E. (2010). The importance of the firm and destination effects to explain firm performance.Tourism Management, 31(1), 22-28. http://dx.doi.org/10.1016/j.tourman.2009.02.009

Narver, J., \& Slater, S. (1990). The effect of market orientation on business profitability. Journal of Marketing, 50(3), 20 - 35. doi: 1251757

O'Cass, A., \& Ngo, L. V. (2011). Achieving customer satisfaction in services firms via branding capability and customer empowerment. Journal of Services Marketing, 25(7), 489-496. doi: $10.1108 / 08876041111173615$

Parasuraman, A., Zeithaml, V. A., \& Berry, L. L. (1985). A conceptual model of service quality and its implications for future research. The Journal of Marketing, 49(4), 41-50. 1251430

Polonsky, M. J., \& Garma, R. (2006). Service blueprinting: a potential tool for improving causedonor exchanges. Journal of Nonprofit \& Public Sector Marketing, 16(1-2), 1-20. doi: 10.1300/J054v16n01_01

Prahalad, C.K., \& Ramaswamy, V. (2004). Co-creation experiences: the next practice in value 
creation. Journal of Interactive Marketing, 18 (3), 5-14. doi: 10.1002/dir.20015

Randall, L. (1993). Perceptual blueprinting. Managing Service Quality, 3(4), 7-12. doi: 10.1108/EUM0000000003173

Raudenbush, S. W., \& Bryk, A. S. (2001). Hierarchical linear models: Applications and data analysis methods (Vol. 1). Sage Publications, Incorporated.

Raudenbush, S. W., \& Bryk, A. S. (2002). Hierarchical linear models: Applications and data analysis methods (2nd ed.). Thousand Oaks, CA: Sage.

Scott, S. G., \& Bruce, R. A. (1994). Determinants of innovative behaviour: A path model of individual innovation in the workplace. Academy of Management Journal, 37(2), 580-607. doi: $10.2307 / 256701$

Shostack, G.L. (1982). How to design a service. European Journal of Marketing, 16(1),49-63. doi: 10.1108/EUM0000000004799

Shostack, G. L. (1984). Designing services that deliver. Harvard Business Review, 62(1), 133-139. doi: $10.1225 / 84115$

Shostack, G. L. (1987). Service positioning through structural change. The Journal of Marketing, 3443. 1251142

Vargo, S. L., Maglio, P. P., \& Akaka, M. A. (2008). On value and value co-creation: A service systems and service logic perspective. European Management Journal, 26(3), 145-152. doi: 10.1016/j.emj.2008.04.003

Walsh, G., \& Mitchell, V. W. (2010). The effect of consumer confusion proneness on word of mouth, trust, and customer satisfaction. European Journal of Marketing, 44(6), 838-859. doi:10.1108/03090561011032739 
Wang, S., Beatty, S. E., \& Liu, J. (2012). Employees' Decision Making in the Face of Customers' Fuzzy Return Requests. Journal of Marketing, 76(6), 69-86. doi: 10.1509/jm.10.0529

Yi, Y., Nataraajan, R., \& Gong, T. (2011). Customer participation and citizenship behavioural influences on employee performance, satisfaction, commitment, and turnover intention. Journal of Business Research, 64(1), 87-95. http://dx.doi.org/10.1016/j.jbusres.2009.12.007

Yim, C. K., Chan, K. W., \& Lam, S. S. (2012). Do Customers and Employees Enjoy Service Participation? Synergistic Effects of Self- and Other-Efficacy. Journal of Marketing, 76 (6), 121-140. doi: 10.1509/jm.11.0205

Zeithaml, V. A., Berry, L. L., \& Parasuraman, A. (1996). The behavioural consequences of service quality. The Journal of Marketing, 60(2), 31-46. doi:10.2307/1251929

Zeithaml, V.A., \& Bitner, M.J. (2000). Services marketing - Integrating customer focus across the firm. (2nd ed.). The McGraw Companies, Inc., New York. 
Figure 1: Conceptual Framework

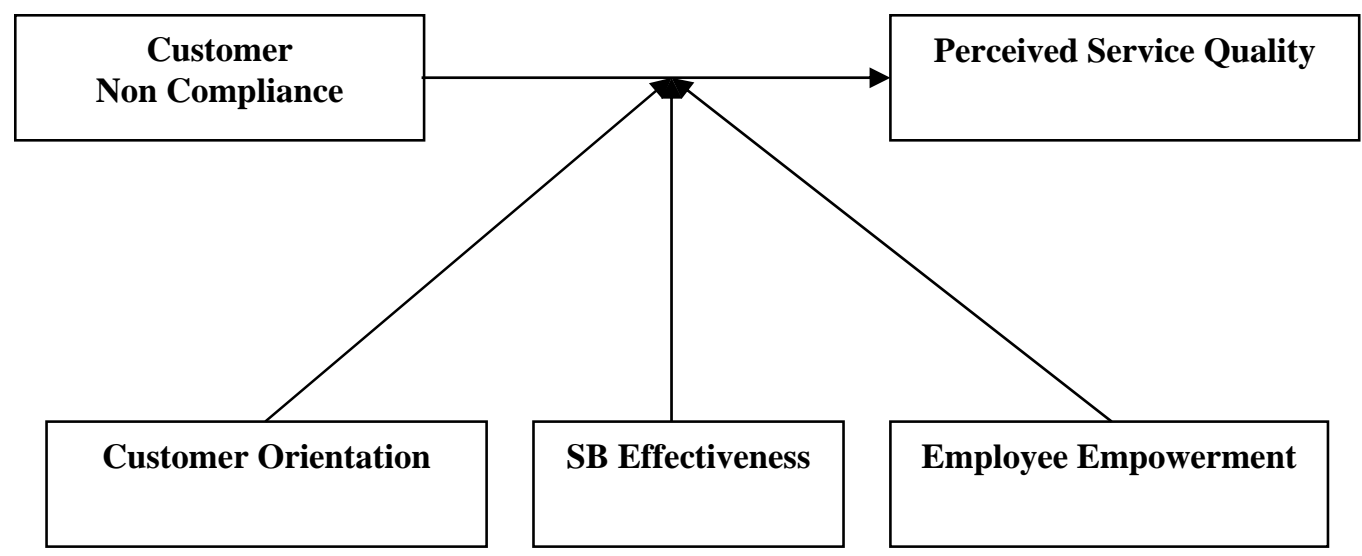


Table 1: Hotels' characteristics

\begin{tabular}{lcc}
\hline Rating & Frequency & Percentage \\
\hline $3^{*}$ & 26 & $21.7 \%$ \\
\hline $4^{*}$ & 60 & $50 \%$ \\
\hline $5^{*}$ & 34 & $28.3 \%$ \\
\hline Total & $\mathbf{1 2 0}$ & $\mathbf{1 0 0 \%}$ \\
\hline Number of Employees & Frequency & Percentage \\
\hline Lees than 40 & 16 & $13,33 \%$ \\
\hline $41-60$ & 27 & $22,5 \%$ \\
\hline $61-80$ & 22 & $18,33 \%$ \\
\hline $81-100$ & 11 & $9,16 \%$ \\
\hline $101-120$ & 20 & $16,66 \%$ \\
\hline More than 120 & 24 & $20 \%$ \\
\hline Total & $\mathbf{1 2 0}$ & $\mathbf{1 0 0 \%}$ \\
\hline Number 0 Beds & &
\end{tabular}

Number of Beds

Mean: 193,4, St Dev: 44,3 
Table 2: Key informants participating in the sample

\begin{tabular}{lcc}
\hline Key Informants & Frequency & Percent \\
\hline General Manager - Owner & 36 & $30 \%$ \\
\hline Operations Director & 28 & $23,3 \%$ \\
\hline Department Director & 22 & $18,3 \%$ \\
\hline HR Director & 14 & $11,6 \%$ \\
\hline Quality Control Manager & 7 & $5,8 \%$ \\
\hline Marketing Director & 5 & $4,2 \%$ \\
\hline Other Manager & 8 & $6,7 \%$ \\
\hline Total & $\mathbf{1 2 0}$ & $\mathbf{1 0 0 \%}$ \\
\hline
\end{tabular}


Table 3: Customers' Demographic Profile and Purpose of Visit

\begin{tabular}{|c|c|c|}
\hline Gender & $\begin{array}{l}\text { Male } \\
58.6 \%\end{array}$ & $\begin{array}{c}\text { Female } \\
41.4 \%\end{array}$ \\
\hline Nationality & Frequency & Percentage \\
\hline Greek & 371 & $63,41 \%$ \\
\hline British & 55 & $9,4 \%$ \\
\hline German & 42 & $7,1 \%$ \\
\hline Dutch & 26 & $4,44 \%$ \\
\hline American & 24 & $4,1 \%$ \\
\hline Italian & 15 & $2,56 \%$ \\
\hline Russian & 11 & $1,88 \%$ \\
\hline Other & 21 & $3,58 \%$ \\
\hline No answer & 20 & $3.41 \%$ \\
\hline Total & 585 & $100 \%$ \\
\hline Age & Frequency & Percentage \\
\hline Under 20 & 25 & $4,27 \%$ \\
\hline $20-25$ & 71 & $12,13 \%$ \\
\hline $26-35$ & 187 & $31,96 \%$ \\
\hline $36-45$ & 152 & $25,98 \%$ \\
\hline $46-55$ & 82 & $14,01 \%$ \\
\hline Over 56 & 37 & $6,32 \%$ \\
\hline No answer & 31 & $5,29 \%$ \\
\hline Total & 585 & $100 \%$ \\
\hline Purpose of visit & Frequency & Percentage \\
\hline Pleasaure & 390 & $66,8 \%$ \\
\hline Business & 90 & $15.3 \%$ \\
\hline $\begin{array}{l}\text { Combination of business and } \\
\text { pleasure }\end{array}$ & 105 & $17.9 \%$ \\
\hline Total & 585 & $100 \%$ \\
\hline
\end{tabular}


Table 4: Scales' Items

Managers' Questionnaire

Customer Orientation

\begin{tabular}{|l|l}
\hline Item 1 & If we find out that customers are dissatisfied with the quality of our
\end{tabular} products/services we immediately take corrective actions.

\begin{tabular}{l|l} 
Item 2 & Somehow we tend to ignore changes to our customers' service needs.
\end{tabular}

\begin{tabular}{l|l} 
Item 3 & We regularly check our product/service developments to assess
\end{tabular} whether they are in line with customer needs.

\begin{tabular}{l|l}
\hline Item 4 & The services we sell are determined more by internal politics than
\end{tabular} market needs.

\begin{tabular}{l|l} 
Item 5 & Customer satisfaction data are regularly distributed to all
\end{tabular} departments.

\begin{tabular}{l|l} 
Item 6 & Customer complaints fall on deaf ears in this firm.
\end{tabular}

SB Effectiveness

\begin{tabular}{|l|l} 
Item 1 & The Service Blueprint describes standard procedures to deal with al
\end{tabular} possible cases.

\begin{tabular}{l|l}
\hline Item 2 & Well defined operating procedures that each employee must follow
\end{tabular} are included in the Service Blueprint

Item $3 \quad$ An employee here can take over other employee's unfinished cases easily by following the operating procedures described in the Service Blueprint.

\begin{tabular}{l|l} 
Item 4 & The Service Blueprint illustrates an understandable sequence of steps
\end{tabular} that can be followed to perform all job tasks.

\begin{tabular}{l|l} 
Item 5 & All possible fail points of the service delivery process are included
\end{tabular} within the Service Blueprint.

\begin{tabular}{l|l} 
Item 6 & More than one adequate solution is described in the Service
\end{tabular} Blueprint, for every possible fail point in the service delivery process.

$\begin{array}{ll}\text { Item } 7 & \text { More than one alternative scenario for delivering the service is }\end{array}$ described in the Service Blueprint.

\begin{tabular}{l|l} 
Item 8 & An employee can look up for assistance in the Service Blueprint
\end{tabular} when dealing with an extraordinary issue.

\begin{tabular}{l|l} 
Item 9 & Can easily follow the instructions described in the service blueprint.
\end{tabular}

Employee Empowerment

\begin{tabular}{l|l} 
Item 1 & We allow employees complete freedom in their work.
\end{tabular}

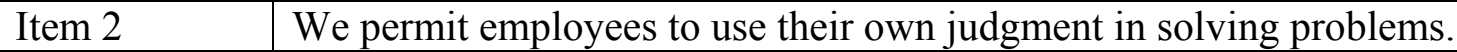

\begin{tabular}{l|l} 
Item 3 & We encourage initiative in my employees.
\end{tabular}

\begin{tabular}{l|l}
\hline Item 4 & I let employees do their work the way they think best.
\end{tabular}

\begin{tabular}{l|l}
\hline Item 5 & We turn employees loose on a job, and let them go to it.
\end{tabular}

\begin{tabular}{l|l} 
Item 6 & We allow employees a high degree of initiative.
\end{tabular}

Managers' Questionnaire

Perceived Service Quality

\begin{tabular}{|l|l}
\hline Item 1 & The specific hotel has up-to-date equipment.
\end{tabular}

\begin{tabular}{|l|l}
\hline Item 2 & The specific hotel's physical facilities are visually appealing.
\end{tabular}

\begin{tabular}{l|l} 
Item 3 & The specific hotel's employees are well dressed and appear neat.
\end{tabular}

Item $4 \quad$ The appearance of the physical facilities of the specific hotel is in keeping with the type of service provided.

Item 5 When the specific hotel promises to do something by a certain time, it does so. 
Table 4: Scales' Items (cont.)

\begin{tabular}{|c|c|}
\hline Item 6 & $\begin{array}{l}\text { When you have problems, the specific hotel is sympathetic and } \\
\text { reassuring. }\end{array}$ \\
\hline Item 7 & The specific hotel is dependable. \\
\hline Item 8 & $\begin{array}{l}\text { There is nothing to be afraid, while having a transaction with the } \\
\text { hotel. }\end{array}$ \\
\hline Item 9 & $\begin{array}{l}\text { The specific hotel provides its services at the time it promises to do } \\
\text { so. }\end{array}$ \\
\hline Item 10 & The specific hotel keeps its records accurately. \\
\hline Item 11 & $\begin{array}{l}\text { The specific hotel does not tell its customers exactly when services } \\
\text { will be performed. }\end{array}$ \\
\hline Item 12 & $\begin{array}{l}\text { You do not receive prompt service from the specific hotel's } \\
\text { employees. }\end{array}$ \\
\hline Item 13 & $\begin{array}{l}\text { Employees of the specific hotel are not always willing to help } \\
\text { customers. }\end{array}$ \\
\hline Item 14 & $\begin{array}{l}\text { Employees of the specific hotel are too busy to respond to customer } \\
\text { requests promptly. }\end{array}$ \\
\hline Item 15 & You can trust employees of the specific hotel. \\
\hline Item 16 & $\begin{array}{l}\text { You can feel safe in your transactions with the specific hotel's } \\
\text { employees. }\end{array}$ \\
\hline Item 17 & Employees of the specific hotel are polite. \\
\hline Item 18 & $\begin{array}{l}\text { Employees get adequate support from the specific hotel to do their } \\
\text { jobs well. }\end{array}$ \\
\hline Item 19 & The specific hotel does not give you individual attention. \\
\hline Item 20 & Employees of the specific hotel do not give you personal attention. \\
\hline Item 21 & Employees of the specific hotel do not know what your needs are. \\
\hline Item 22 & The specific hotel does not have your best interests at heart. \\
\hline \multicolumn{2}{|c|}{ Customer Compliance } \\
\hline Item 1 & The employees of the hotel got my full cooperation. \\
\hline Item 2 & $\begin{array}{l}\text { During the service provision, I followed carefully the directions the } \\
\text { employees gave me. }\end{array}$ \\
\hline Item 3 & I read carefully all printed directions and rules. \\
\hline Item 4 & When I used the hotel's equipment, I left it back where I was told to. \\
\hline Item 5 & $\begin{array}{l}\text { I tried to attend hotel's activities (breakfast, check out, sports) the } \\
\text { hours the hotel recommended. }\end{array}$ \\
\hline Item 6 & $\begin{array}{l}\text { Sometimes I didn't follow the employees' instructions, because I } \\
\text { thought that they would cause me inconvenience. }\end{array}$ \\
\hline Item 7 & I helped the employees to do their jobs \\
\hline
\end{tabular}


Table 5: Confirmatory Factor Analysis, Reliability and Validity of Constructs

\begin{tabular}{lcccccc}
\hline Constructs & CFI & TLI & RMSEA & AVE & $\begin{array}{c}\text { Composite } \\
\text { Reliability }\end{array}$ & $\begin{array}{c}\text { Crobach } \\
\text { a }\end{array}$ \\
\hline Customer Orientation & 0.972 & 0.938 & 0.078 & 0.71 & 0.84 & 0.910 \\
SB Effectiveness & 0.952 & 0.944 & 0.074 & 0.67 & 0.82 & 0.856 \\
$\begin{array}{l}\text { Employee Empowerment } \\
\text { Customer Compliance }\end{array}$ & 0.974 & 0.942 & 0.064 & 0.57 & 0.72 & 0.817 \\
\begin{tabular}{l} 
Perceived Service Quality \\
\hline
\end{tabular} & 0.956 & 0.944 & 0.078 & 0.60 & 0.68 & 0.876 \\
\hline
\end{tabular}


Table 6: Variables' Descriptive Statistics and Normality Tests

\begin{tabular}{lcccccc}
\hline \multicolumn{7}{c}{ Descriptive statistics - Normality Tests } \\
\hline & N & Mean & St Dev & Asymmetry & Kurtosis & $\begin{array}{c}\text { Kolmogorov- } \\
\text { Smirnov p-value }\end{array}$ \\
\hline $\begin{array}{l}\text { Customer } \\
\text { Orientation }\end{array}$ & 120 & 5,152 & 1,192 & $-0,423$ & $-0,850$ & 0.082 \\
\hline SB Effectiveness & 120 & 4,724 & 1,345 & $-0,281$ & $-0,719$ & 0.142 \\
\hline $\begin{array}{l}\text { Employee } \\
\text { empowerment }\end{array}$ & 120 & 4,029 & 0,966 & 0,114 & $-0,494$ & 0.054 \\
\hline $\begin{array}{l}\text { Perceived Service } \\
\text { Quality }\end{array}$ & 585 & 4.902 & 1.423 & -0.429 & -0.568 & 0.171 \\
\hline $\begin{array}{l}\text { Customer Non- } \\
\text { compliance }\end{array}$ & 585 & 3.609 & 1,552 & $-0,675$ & $-0,933$ & 0.045 \\
\hline
\end{tabular}


Table 7: Hierarchical Linear Modeling Results

\begin{tabular}{|c|c|c|c|c|c|}
\hline Fixed Effect & Coefficient & Standard Error & t-ratio & Ap. d.f. & p-value \\
\hline$\gamma_{00}$ & 4.310342 & 0.088094 & 48.929 & 119 & $<0.001$ \\
\hline$\gamma_{10}$ & -0.187471 & 0.040750 & -4.601 & 461 & $<0.001$ \\
\hline$\gamma_{11}$ & 0.135636 & 0.033345 & 4.068 & 461 & $<0.001$ \\
\hline$\gamma_{12}$ & 0.153726 & 0.065460 & 4.127 & 461 & $<0.001$ \\
\hline$\gamma_{13}$ & 0.149352 & 0.041171 & 3.628 & 461 & $<0.001$ \\
\hline Random Effect & $\begin{array}{l}\text { Standard } \\
\text { Deviation }\end{array}$ & $\begin{array}{c}\text { Variance } \\
\text { Component }\end{array}$ & d.f. & $\chi^{2}$ & p-value \\
\hline INTRCPT1, uo & 0.47034 & 0.22122 & 119 & 177.69828 & $<0.001$ \\
\hline Level-1, $r$ & 1.42099 & 2.01921 & & & \\
\hline
\end{tabular}

